\title{
Fostering management education to deter corruption: what do students know about corruption and its legal consequences?
}

\author{
Katharina Becker • Christian Hauser • \\ Franz Kronthaler
}

Published online: 22 May 2013

(C) Springer Science+Business Media Dordrecht 2013

\begin{abstract}
This article analyses the current knowledge about corruption and its legal consequences among university students. Based on data from 1,511 undergraduate and graduate students from all academic disciplines at four major universities in the German-speaking part of Switzerland, it appears that the majority of students have difficulty identifying corrupt behaviour and its legal consequences. Law students achieve slightly better results. However, even law students demonstrate a significant lack of knowledge of corruption issues. In particular, most of the students are unaware that corruption that occurs abroad can also be prosecuted in Switzerland. The limited knowledge among students regarding corruption and its legal consequences as identified in this study suggests that the teaching and study of anticorruption-related subjects should be better integrated into the curricula of universities and business schools.
\end{abstract}

JEL Classification $\mathrm{K} 40 \cdot \mathrm{I} 20 \cdot \mathrm{M} 53$

\section{Introduction}

In recent years, governments of many developed and developing countries have strengthened their anti-corruption efforts by redefining and reinforcing criminal laws regarding bribery and corruption, as well as by strengthening the enforcement of such laws. According to the new international legal norms, the bribery of foreign public officials is regarded as a criminal offence, not only for individuals but also for companies, which can now be prosecuted for corruption. Furthermore, bribing a foreign public official is a criminal offence that can be prosecuted in one's home country even when the bribery occurs abroad. Hence, companies and professionals operating abroad need to maintain compliance with both domestic and foreign laws.

K. Becker $\cdot$ C. Hauser $(\bowtie) \cdot$ F. Kronthaler

University of Applied Sciences HTW Chur, Chur, Switzerland

e-mail: christian.hauser@htwchur.ch 
Despite these profound and far-reaching changes in the legal regulations concerning bribery and corruption, a recent survey of the International Bar Association (IBA), in cooperation with the Organisation for Economic Co-operation and Development (OECD) and the United Nations Office on Drugs and Crime (UNODC), identified a serious lack of awareness of international corruption laws and risks even among legal professionals. Many lawyers were unaware of the implications of the existing international anti-corruption regulatory framework. Based on the survey results, the authors conclude that law students might not be sufficiently trained about this subject before entering professional practice [15].

As future specialists, executives or entrepreneurs, students are of critical importance in the fight against bribery and corruption, because they will influence business activities once they gain decision-making authority [28, 29]. Given the ubiquity of corruption, several international initiatives have been developed which are intended to promote the inclusion of anti-corruption-related subjects in management education curricula at universities and business schools. These initiatives include the United Nations Principles for Responsible Management Education (PRME) Working Group on Anti-Corruption. In July 2012, the working group launched its guidelines for MBA curriculum change during the United Nations Conference on Sustainable Development $($ Rio +20$)$ held in Rio de Janeiro, Brazil. The guidelines contain a wide-ranging set of academic anti-corruption tools that lecturers could integrate into their syllabi, including a variety of related topics, examples of anti-corruption course plans, and resources such as case studies and bibliographies. These materials are made available at no cost to the academic community to support lecturers in all academic disciplines in introducing anti-corruption courses in their universities and business schools, with a particular focus on law, business, international relations and social science programmes [19].

However, before insisting on introducing such new subject matter into the curricula of universities and business schools on either a compulsory or an elective basis, researchers should first obtain empirical evidence of the necessity of this additional content. It could be argued that the introduction of specific anti-corruption teaching is only required if students have insufficient knowledge about bribery and corruption.

Therefore, this study investigates the current knowledge levels of university students regarding corruption and its legal consequences. The primary research objective of this study is to examine whether university students are capable of recognising corrupt practices in domestic or international business operations, and whether they are able to accurately assess the legal consequences of these practices. Furthermore, several socio-demographic factors that may influence student knowledge should be studied, including the students' field of study, the duration of their work experience, their academic level and their gender. To examine these factors, a survey was conducted among undergraduate and graduate students from all academic disciplines from four major universities located in the German-speaking part of Switzerland. Based on the results, recommendations for universities and companies can be generated. If the study's findings show that student knowledge is considerably imprecise or incorrect, it could be argued that faculty should provide more training, information and resources related to the issue of corruption. Based on the seminal work and conceptual considerations of Ghoshal [12], it could be argued that management education has a significant impact on the future practice of management. 
According to Ghoshal, a student's future judgments and behaviour are influenced by the concepts and knowledge acquired during the education at universities or business schools. On the other hand, if students already have a high level of knowledge in this area, it implies that the introduction of anti-corruption curricula is not urgently necessary, at least for the studied sample group.

This paper is organised as follows. Section 2 briefly outlines the relevant literature on corruption and bribery. Based on the current available literature, specific research questions are generated regarding the current knowledge of university students about corruption and its legal consequences. The subsequent sections address the empirical study and discuss the data, the methodology, the variables used, and the results. Finally, concluding remarks are presented.

\section{Literature review and research question}

In recent years, the body of research related to corruption has expanded within different disciplines, including history, law, political sciences, psychology, sociology, business administration and economics. The majority of the existing economics literature on corruption focuses on macroeconomic issues [23]. The results of these studies identify corruption as a significant problem and prove its serious negative consequences (e.g., [9, 18]). Despite these known negative effects, studies indicate that corruption is still widespread in international business. It is estimated that bribery payments of approximately 1 trillion US dollars are paid annually across the globe [21]. This makes corruption one of the most challenging problems for companies and professionals operating overseas.

Corrupt transactions are illicit and involve undisclosed arrangements between two or more persons. Therefore, in recent years, the involvement of individuals in corrupt practices has emerged as an increasingly important new area of investigation within economic research [14, 27]. So far, however, there is limited insight into human behaviour as it relates to corruption. The initial research on this issue has addressed the demographic characteristics, individual attitudes and behavioural patterns of decision makers regarding corruption. For this purpose, Rabl and Kühlmann [20] developed a theoretical model that focuses on the decision-making process among corrupt actors and highlights the interplay between personal characteristics and context. Based on a sample of university students, these researchers identified three factors that influence the decision-making process that leads to corrupt behaviour: the individual's attitude towards corruption, subjective norms that favour corruption and perceived behavioural control. The results obtained by Dong et al. [10] indicate that a person's propensity to engage in corrupt practices is influenced by the perceived behaviour of the individual's peers and other actors. McKinney and Moore [17] investigate the attitudes of professionals towards corruption in international business transactions. They show that business professionals from firms with written codes of ethics were significantly less likely to find bribery acceptable than were those who worked for firms without such a code of conduct. Collins et al. [7] show that the likelihood that a firm will engage in corruption is positively related to the degree its top decision makers perceive corruption as a normal part of doing business. Furthermore, executives can trigger corrupt behaviour among the people they manage by establishing unrealistic business objectives and 
deadlines, as well as by implementing, tolerating or overlooking questionable practices that are used to meet them $[2,8]$.

In the literature, it is widely acknowledged that education is a crucial factor in anticorruption efforts, because only training seems to sufficiently prevent the inappropriate attitudes and behavioural patterns that are perpetuated within generations of decision makers $[4,8,11,26]$. Scholars argue that the moral attitudes of today's university students will influence the future ethical climate of business, because students' beliefs and attitudes regarding to what constitutes responsible business conduct will influence the perceptions and behaviours they will demonstrate in their future working lives $[12,13,16]$.

However, the dominant management education paradigm has frequently been viewed as part of the problem of unethical business practices, not least because many of the perpetrators involved in recent corruption scandals are alumni of the most distinguished universities and business schools in the world [3, 5, 6]. Borkowski and Ugras [6] compared the attitudes of freshmen and older undergraduate business students with those of graduate MBA students regarding ethical dilemmas, showing that, whereas freshmen and undergraduate business students tend to be more justiceoriented, graduate MBA students tend to be more utilitarian in their ethical approach. Analysing the ethical standards of undergraduate students in different fields of study, Tse and $\mathrm{Au}$ [25] found no significant differences between the ethical positions of business students and non-business students. Jaffe and Tsimerman [16] investigated the ethics of Russian business students and compared the results with those of similar surveys that examined the attitudes of Russian managers. The study shows that the former are more pessimistic than the latter and that a large proportion of students think that in the business world one must inevitably compromise one's ethical principles. The findings presented by Crittenden et al. [8] support the contention that environmental factors exert a significant impact on ethical attitudes. Students from countries in which corruption is endemic tend to be more likely to express lower ethical standards than are students from less corrupt countries. For instance, the former are more likely to use existing laws as their ethical reference point, suggesting that there are no higher standards for behaviour than the existing laws. At the same time, they are also more likely to perceive unethical business practices as a necessity.

In summary, the existing literature shows that corruption is prevalent in many countries and that it causes serious damage at different levels. The fact that corruption has significant negative effects and leads to the inefficient allocation of limited resources has led to increased national and international efforts to prevent bribery and corruption, particularly in recent years. For example, in 1997, the OECD Convention on Combating Bribery of Foreign Public Officials in International Business Transactions was signed; the agreement entered into force in 1999. Furthermore, in 1999, the Council of Europe Criminal Law Convention on Corruption was opened for signature in Strasbourg; it came into force in 2002. Additionally, in 2003, the United Nations Convention against Corruption was adopted by more than 100 countries, including Switzerland; the agreement entered into force in 2005. Based on these international agreements, Switzerland and many other developed countries redefined and reinforced their criminal laws on bribery and corruption, particularly with regard to international business transactions. According to the new legislation, both individuals and companies can be prosecuted if they participate in corrupt 
practices. In addition, anyone who bribes a foreign public official not only commits a criminal offence abroad but can also be prosecuted in Switzerland [22].

The existing literature also indicates that there is a high probability that executives and employees of internationally operating companies will encounter illegal behaviour during their careers. Therefore, it is increasingly important that representatives of firms know which behaviours and practices are inconsistent with domestic and international laws and will have legal consequences. Because university students are the world's future decision makers, they must be sufficiently informed and trained to ensure that they can act appropriately in their future business lives. Therefore, at this time, different international initiatives are being undertaken to help management education deter corruption, including the anti-corruption guidelines for MBA curriculum change developed by the United Nations Principles for Responsible Management Education (PRME) Working Group on Anti-Corruption [19].

However, according to the concept of the transformative learning theory, moral learning in adulthood is a challenging task, because learners have to critically reflect on their own knowing and believing in the aim of transforming their frame of reference. In order to initiate such a critical learning process, lecturers need information about their students' awareness of, attitudes towards and knowledge about corruption, so that they can build on or challenge their frame of reference [5]. Although there is some research on the attitudes and perceptions of students regarding corruption, there is no specific information in the literature regarding students' knowledge about corruption and its legal consequences. Thus, our study extends the existing literature by examining the current knowledge levels of university students regarding domestic and foreign legislation on corruption, and by analysing whether specific sociodemographic characteristics have an influence on such knowledge. Hence, our study addresses the following two research questions:

To what extent are university students able to recognise corrupt practices in domestic and international business transactions and accurately assess the legal consequences of these practices?

Do socio-demographic factors such as field of study, extent of work experience, academic level and gender have a significant influence on students' knowledge in this area?

\section{Methods and sample}

Our focus is on the knowledge of students on corrupt business practices and its legal consequences. This information is not available from secondary sources. Instead, we used data provided by a large-scale online survey undertaken at universities located in the German-speaking part of Switzerland between June and July 2010. The principals of the 19 existing universities were asked to forward the questionnaire to their students, whereby 4 of them did. Altogether, the survey was forwarded with a onetime mailing to approximately 44,000 students enrolled at these universities. Hence, the mailing comprised around $35 \%$ of the students enrolled at the universities in the German-speaking part of Switzerland. In total, we received 1,511 usable responses, with a response rate of $3 \%$. Considering the respondents' study field (see Table 1), it can be seen that $13.1 \%$ were studying humanities, $5.4 \%$ jurisprudence, $20.3 \%$ 
Table 1 Distribution of the respondents according to their fields of study

\begin{tabular}{llr}
\hline Fields of study & Number of students & Percent \\
\hline Humanities & 198 & 13.1 \\
Jurisprudence & 81 & 5.4 \\
Economics and social sciences & 306 & 20.3 \\
Natural sciences & 530 & 35.1 \\
Engineering & 290 & 19.2 \\
Others & 96 & 6.4 \\
Missing values & 10 & 0.7 \\
Total & 1,511 & 100.0 \\
\hline
\end{tabular}

economics and the social sciences, $35.1 \%$ the natural sciences and $19.2 \%$ engineering. The remaining $6.4 \%$ of the students were enrolled in other study fields.

The response rate is rather low, which is not unusual for online surveys and such topics. Nevertheless, the question remains whether there is a non-response bias within the data. To get some indication of this, we compared the percentages of the respondents' study fields with the actual proportions at the universities as well as the gender share. With regard to the breakdown of the study fields, we found no statistical significance between the respondents and total students at the four universities. Hence, there is no indication for a non-response bias with regard to the study field. The comparison of the gender shares of the survey with the gender shares at the four universities shows that male students are slightly overrepresented whereas female students are slightly underrepresented. The share of male students in the survey is $58.5 \%$ compared to $54.2 \%$ at the four universities. Whilst this difference is statistically significant, it is in practice rather low. Additionally, following Armstrong and Overton [1], a third test was conducted to assess the data for a potential non-response bias. The comparison of the response behaviour of early respondents and late respondents shows no significant difference between the response behaviour of the different groups, indicating that there is no problem with a non-response bias. Altogether, the sample seems to be a good representation of the target population.

To study the knowledge of students about corruption and its legal consequences, the questionnaire presented students with seven short case studies describing hypothetical business situations in which corruption issues might occur. ${ }^{1}$ The case studies were designed as real business situations. To ensure the validity of the case studies, executives of international firms and experts of Transparency International were asked to evaluate the cases. An example of a case study is as follows (the other case studies are described in the Appendix):

“A Swiss company pays a 'consulting fee' of CHF 350,000 to a foreign public official. In return, the foreign public official promises assistance in obtaining a public contract, which should produce a CHF 10 million profit for the company."

Students were asked to evaluate whether the described business scenario includes corrupt practices that can be criminally prosecuted according to existing laws. In

\footnotetext{
${ }^{1}$ McKinney and Moore [17] used a similar approach to study attitudes of business people towards bribery.
} 
particular, they assessed whether one of the two actors involved, the Swiss company or the foreign public official, or both, committed a criminal offence in Switzerland and/or abroad, assuming that the same legal standards are applied both in Switzerland and abroad. Case studies were designed differently to consider several business situations. Four of the case studies describe international business transactions, whereas three of them are restricted to domestic business situations. Furthermore, different corrupt practices are taken into account. Five case studies describe the possible use of active and passive bribery. The other two case studies refer to illegal gratuities. ${ }^{2}$ To ensure validity, not all business situations included actions which are prosecuted legally. To test the knowledge of students and to reduce correct answers by chance, only three case studies describe business transactions that are considered to be illegal according to existing domestic and international laws, whereas four describe business transactions that are considered to be legal. Due to the topic of the questionnaire, it might be the case that students would expect illegal business actions within the case studies. In cases of uncertainty with a situation, they hence might have a higher probability to evaluate the action as illegal. By involving more legal business cases, this is taken into account. Hence, much is done to establish validity. Besides this, it is important that students study the case studies seriously. With regard to the results (see below), it is hoped that students are able to better judge when they are later involved in real business situations.

\section{Results}

The results indicate that students seem to lack knowledge regarding the judicial consequences of corrupt practices. On average, students were only able to evaluate 2.6 out of the seven cases correctly. This means that in general, more than four of the seven cases were assessed incorrectly. Approximately $7 \%$ of the students were not able to properly evaluate any of the cases, and $73 \%$ could only assess three or fewer cases correctly. Only $6.8 \%$ of the surveyed students could evaluate five or more cases accurately (Table 2).

In particular, the results indicate that the majority of students do not know that corrupt behaviour that occurs abroad also has legal consequences in Switzerland (Table 3). In four of the seven cases, the respondents were asked to evaluate if an illegal business transaction conducted abroad also could be prosecuted in Switzerland. The results show that the students were better able to assess the legal consequences of the transaction abroad. Indeed, whereas $50 \%$ of the participants correctly identified the legal consequences abroad for more than two cases, the majority of the students seem unaware that corrupt behaviour abroad is also a criminal offence in Switzerland: only $17 \%$ of the respondents correctly assessed the consequences in Switzerland for more than two cases.

\footnotetext{
${ }^{2}$ According to international definitions, bribery is considered to be a payment or other advantages in order to influence a decision. Illegal gratuities are actions that reward the decision maker after a favourable decision is made (see [24]).
} 
Table 2 Number of correctly assessed cases

\begin{tabular}{llrr}
$\begin{array}{l}\text { Number of correctly } \\
\text { assessed cases }\end{array}$ & No. of respondents & Percent & $\begin{array}{l}\text { Cumulative } \\
\text { percent }\end{array}$ \\
\hline 0 & 104 & 6.9 & 6.9 \\
1 & 207 & 13.7 & 20.6 \\
2 & 358 & 23.7 & 44.3 \\
3 & 433 & 28.7 & 72.9 \\
4 & 307 & 20.3 & 93.2 \\
5 & 84 & 5.6 & 98.8 \\
6 & 17 & 1.1 & 99.9 \\
7 & 1 & 0.1 & 100.0 \\
Total & 1,511 & 100.0 & \\
\hline
\end{tabular}

In summary, it seems that the majority of the surveyed students seriously lack knowledge of corrupt behaviour and its legal consequences.

To conduct a more detailed analysis of the students' current knowledge levels, we investigated whether socio-demographic factors such as field of study, extent of work experience, academic level and gender influence such knowledge.

One might expect that students who study law or economics and the social sciences should be more capable of assessing these cases correctly. Because of their exposure to judicial issues, law students could be expected to be well aware of the potential legal consequences of corruption. The same should be true of students who study economics or the social sciences, because they examine economically and socially relevant topics and therefore should be more familiar with corruption issues than, for instance, students in the humanities, natural sciences or engineering. However, the cross-tabulation (Table 4) shows only minor differences in this regard. Only the law students appear to be slightly better informed.

Variance analysis was used to confirm these results. The null hypothesis, that there is no difference between the groups with regard to the number of correctly assessed cases, can be rejected with an error probability of less than $5 \%$ (Table 5 ). Both the

Table 3 Number of correctly assessed cases: legal consequences in Switzerland and abroad

\begin{tabular}{|c|c|c|c|c|c|c|}
\hline \multirow{2}{*}{$\begin{array}{l}\text { Number of correctly assessed } \\
\text { cases }\end{array}$} & \multicolumn{3}{|c|}{ Legal consequences in Switzerland } & \multicolumn{3}{|c|}{ Legal consequences abroad } \\
\hline & $\begin{array}{l}\text { No. of } \\
\text { respondents }\end{array}$ & Percent & $\begin{array}{l}\text { Cumulative } \\
\text { percent }\end{array}$ & $\begin{array}{l}\text { No. of } \\
\text { respondents }\end{array}$ & Percent & $\begin{array}{l}\text { Cumulative } \\
\text { percent }\end{array}$ \\
\hline 0 & 149 & 9.9 & 9.9 & 92 & 6.1 & 6.1 \\
\hline 1 & 354 & 23.4 & 33.3 & 229 & 15.2 & 21.2 \\
\hline 2 & 751 & 49.7 & 83.0 & 435 & 28.8 & 50.0 \\
\hline 3 & 184 & 12.2 & 95.2 & 397 & 26.3 & 76.3 \\
\hline 4 & 73 & 4.8 & 100.0 & 358 & 23.7 & 100.0 \\
\hline Total & 1,511 & 100.0 & & 1,511 & 100.0 & \\
\hline
\end{tabular}




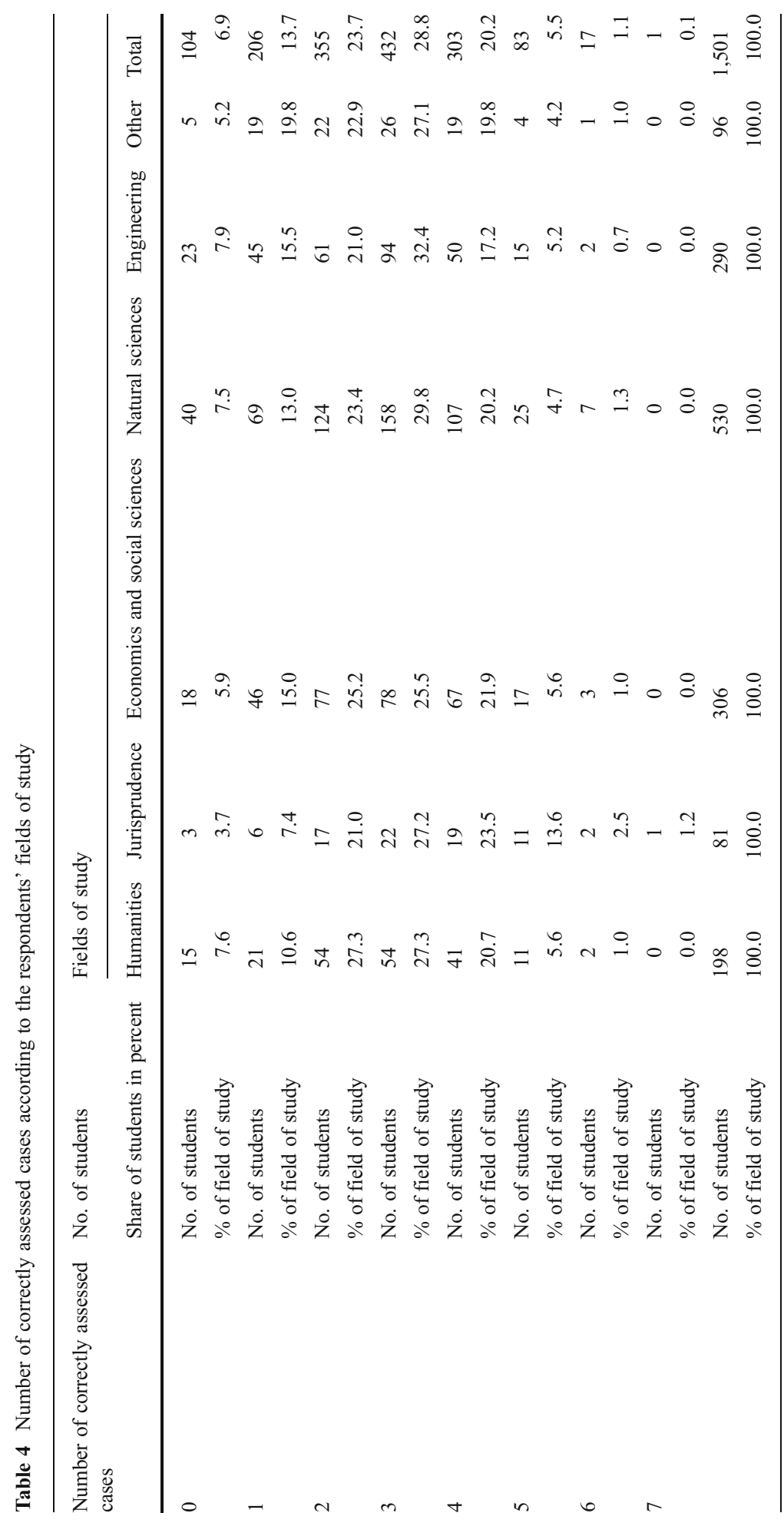


Table 5 Variance analysis of the number of correctly assessed cases by field of study

Dependent variable: number of correctly assessed cases

Sum of squares $\begin{aligned} & \text { Degrees of } \\ & \text { freedom }\end{aligned}$ Mean square $F$ value Level of significance

\begin{tabular}{lrrrrr}
\hline Field of study & 26.32 & 5.00 & 5.26 & 2.93 & 0.01 \\
Unexplained variance & $2,687.47$ & $1,495.00$ & 1.80 & & \\
Total variance & $2,713.79$ & $1,500.00$ & & & \\
\hline
\end{tabular}

LSD test and the Bonferroni test ${ }^{3}$ show that there is only a difference between law students and the students of the other fields of study in this regard. It appears that the law students are generally more capable of correctly assessing the scenarios. However, for the law students, the number of correctly assessed scenarios is also quite low, with 3.1 of seven cases correctly assessed on average.

The academic level of a student could also have an impact on his or her ability to correctly assess international business transactions. Students studying at the postgraduate level (in masters or doctoral programmes) may have developed more advanced reasoning abilities and may have acquired more knowledge than students at the undergraduate level (bachelor programme). However, there is no empirical evidence that supports this hypothesis. The variance analysis shows that the null hypothesis is not rejected (Table 6).

Interestingly, the same holds true with respect to the number of years of work experience that students had acquired in addition to their academic work. The variance analysis shows that the duration of the students' work experience seems to have no impact on the dependent variable, i.e. the number of correctly assessed cases (Table 7). ${ }^{4}$

However, the analysis shows a significant difference between the responses of male and female students. A $t$ test demonstrates that the null hypothesis, that there is no difference between women and men, can be rejected with an error margin of less than $1 \%$ (Table 8 ).

However, the difference between the performance of men and women in the study is low and therefore has almost no practical relevance. On average, men were able to solve 2.8 of seven cases correctly, whereas the mean value of 2.4 for female participants was only slightly lower.

\section{Summary and conclusions}

In recent years, corruption has become an increasingly important topic for both governments and companies. Thus, several international initiatives promote the inclusion of

\footnotetext{
${ }^{3}$ After the variance analysis, the LSD test and Bonferroni test were used to control for between-group differences. The LSD test is known as a liberal test procedure; it hints at many possible significant differences between groups. On the other hand, the Bonferroni test is regarded as very conservative.

${ }^{4}$ The variable "work experience" includes the following categories: no work experience, work experience of up to 1 year, work experience of 1-2 years, work experience of 2-3 years and more than 3 years of work experience. These data do not reflect the quality of the work experience.
} 
Table 6 Variance analysis of the number of correctly assessed cases by academic level

Dependent variable: number of correctly assessed cases

Sum of squares $\begin{aligned} & \text { Degrees of } \\ & \text { freedom }\end{aligned}$ Mean square $F$ value Level of significance
freedom

\begin{tabular}{lrllll}
\hline Academic level & 14.14 & 8 & 1.77 & 0.98 & 0.45 \\
Unexplained variance & $2,622.91$ & 1,451 & 1.81 & & \\
Total variance & $2,637.05$ & 1,459 & & & \\
\hline
\end{tabular}

anti-corruption classes in university and business school programmes based on the conviction that students need to be adequately informed and trained at an early stage to ensure that they are able to act adequately in their future business lives. In this context, the present study examines the current knowledge of university students about corruption and its legal consequences. For this purpose, students from all academic disciplines were asked to evaluate short case studies that described domestic and international business activities. The participants had to assess whether the scenarios included corrupt behaviour or were consistent with the current legal framework and standards. The results indicate that the majority of the students have difficulty identifying corruption and its legal consequences. On average, the surveyed students were only capable of correctly evaluating 2.6 out of the seven cases. In particular, most of the students are unaware that corrupt practices conducted abroad can also be prosecuted in Switzerland. As one might expect, law students achieve slightly better results than did students in other academic disciplines. However, law students also show a grievous lack of knowledge of corruption issues. On average, the future jurists were unable to assess at least half of the given scenarios correctly. Furthermore, the results reveal that the knowledge levels of economics and social science students do not differ significantly from those of students in other academic disciplines, such as the humanities, the natural sciences or engineering. From the results, it is evident that we must increase awareness among and properly train future decision makers to fight corruption successfully. To facilitate this mission, companies and universities must work closely together to develop suitable training models and courses.

At universities and business schools, the imprecise and incorrect understanding of corruption and its legal consequences among students mandates that the discussion of corruption be better integrated into management education curricula. It is also important

Table 7 Variance analysis of the number of correctly assessed cases by duration of work experience

Dependent variable: number of correctly assessed cases

\begin{tabular}{lcllll}
\hline & Sum of squares & $\begin{array}{l}\text { Degrees of } \\
\text { freedom }\end{array}$ & Mean square & $F$ value & Level of significance \\
\hline Work experience & 10.27 & 4 & 2.57 & 1.43 & 0.22 \\
Unexplained variance & $2,644.05$ & 1,477 & 1.79 & & \\
Total variance & $2,654.31$ & 1,481 & & \\
\hline
\end{tabular}


Table 8 Test of the consistency of the responses by gender

Testing variable: number of correctly assessed cases

\begin{tabular}{lllll}
\hline$t$ value & Degrees of freedom & Level of significance & Mean difference & Standard error difference \\
\hline 6.05 & 1,509 & 0.000 & 0.42 & 0.07 \\
\hline
\end{tabular}

for companies to note that students are not sufficiently aware of the issue of corruption upon entering careers in business. Given this general lack of knowledge regarding corruption on the part of students, firms must train their young professionals and employees to help them to remain in compliance with the existing legal framework and ethical standards. Large companies are increasingly recognising the importance of this topic and have begun to incorporate information regarding compliance into their training programmes. For example, they offer specific web-based training and specialised compliance guidelines and helplines. Naturally, however, companies that implement these tools and programmes face higher costs. Such costs are a particular challenge for small and medium-sized enterprises (SMEs). The increased use of anticorruption curricula at universities and business schools would relieve companies of this burden. Co-operation between universities and companies that are pioneers in this area could support and simplify the implementation of the necessary training. Given that $80 \%$ of the surveyed students consider corruption a cost of doing business that cannot be eradicated, it is especially important to promote these actions.

In presenting initial insight into the current knowledge of university students about corruption and its legal consequences, we contribute to the on-going academic discussion of corruption at the individual level. To deepen the discussion and further examine current knowledge about corruption, further research should analyse additional segments of the population, including politicians, business professionals and entrepreneurs. It could also be helpful for future research to explore how knowledge about corruption and its legal consequences affects attitudes towards corrupt behaviour. Additionally, cross-national studies should be conducted to examine the knowledge and attitudes of individuals from other countries and other cultural backgrounds.

\section{Appendix}

Case studies used in the online survey:

Case \#1 The purchasing manager of a big Swiss company retires at the age of 65 . As a reward for the long standing working relationship and close cooperation over many years, his biggest foreign supplier invites him and his wife to an extended wellness-weekend in the Swiss Alps. The purchasing manager gratefully accepts.

Case \#2 A Swiss entrepreneur wants to build an additional warehouse on his own property. To facilitate the building process as quickly as possible within the current financial year, he requests the public official responsible for planning permission to handle the building application as fast as possible. After 
handling the building application promptly and within the required timescale, the entrepreneur thanks the public official with a bottle of wine worth $\mathrm{CHF}$ 120.-, which the public official gratefully accepts.

Case \#3 A Swiss company pays a 'consulting fee' of CHF 350,000 to a foreign public official. In return, the foreign public official promises assistance in obtaining a public contract, which should produce a CHF 10 million profit for the company.

Case \#4 A Swiss entrepreneur wants to expand his business internationally and therefore contacts a self-employed foreign sales agent, who represents several companies in the local market. To celebrate the conclusion of the commission contract, the entrepreneur invites his new sales agent to an exclusive brothel.

Case \#5 The salesman of a Swiss company wants to get into business with a new company. In order to develop a good relationship with the purchasing manager of this company, the salesman invites the purchasing manager and his wife for dinner in a luxury restaurant costing CHF 500.-. During this occasion, they also talk about the placing of a large order.

Case \#6 A medium-sized Swiss company is conducting a large procurement drive to find a new supplier. One supplier, who wants this order at all costs, knows about the entrepreneur's passion for watches. Therefore, the supplier gives the entrepreneur a watch worth CHF 8,000.- as a present. The entrepreneur gratefully accepts.

Case \#7 A Swiss company is participating in a big public procurement in a foreign country. To win the tender, the company assigns a local agent to give $\mathrm{CHF}$ 100,000.- to a high-ranking foreign public official. In return, this public official will ensure that the Swiss company wins the profitable tender.

\section{References}

1. Armstrong, J. S., \& Overton, T. S. (1977). Estimating nonresponse bias in mail surveys. Journal of Marketing Research, 14(3), 396-402.

2. Ashforth, B. E., \& Anand, V. (2003). The normalization of corruption in organizations. Research in Organizational Behavior, 25, 1-52.

3. Ashforth, B. E., Gioia, D. A., Robinson, S. L., \& Treviño, L. K. (2008). Re-viewing organizational corruption. Academy of Management Review, 33(3), 670-684.

4. Beets, S. (2005). Understanding the demand-side issues of international corruption. Journal of Business Ethics, 57(1), 65-81.

5. Blasco, M. (2012). Aligning the hidden curriculum of management education with PRME: an inquirybased framework. Journal of Management Education, 36(3), 364-388.

6. Borkowski, S. C., \& Ugras, Y. J. (1992). The ethical attitudes of students as a function of age, sex and experience. Journal of Business Ethics, 11(12), 961-979.

7. Collins, J. D., Uhlenbruck, K., \& Rodriguez, P. (2009). Why firms engage in corruption: a top management perspective. Journal of Business Ethics, 87(1), 89-108.

8. Crittenden, V. L., Hanna, R. C., \& Peterson, R. A. (2009). Business students' attitudes toward unethical behavior: a multi-country comparison. Marketing Letters, 20(1), 1-14.

9. Della Porta, D., \& Vannucci, A. (2005). The governance mechanisms of corrupt transactions. In J. G. Lambsdorff, M. Taube, \& M. Schramm (Eds.), The new institutional economics of corruption (pp. 152-180). London: Routledge.

10. Dong, B., Dulleck, U., \& Torgler, B. (2012). Conditional corruption. Journal of Economic Psychology, 33(3), 609-627. 
11. Everett, J., Neu, D., \& Rahaman, A. S. (2006). The global fight against corruption: a foucaultian, virtues-ethics framing. Journal of Business Ethics, 65(1), 1-12.

12. Ghoshal, S. (2005). Bad management theories are destroying good management practices. The Academy of Management Learning and Education, 4(1), 75-91.

13. Grünbaum, L. (1997). Attitudes of future managers towards business ethics: a comparison of Finnish and American Business students. Journal of Business Ethics, 16(4), 451-463.

14. Höffling, C. (2002). Korruption als soziale Beziehung. Opladen: Leske + Budrich.

15. IBA, OECD, \& UNODC. (2010). Risks and threats of corruption and the legal profession: Survey 2010.

16. Jaffe, E. D., \& Tsimerman, A. (2005). Business ethics in a transition economy: will the next Russian generation be any better? Journal of Business Ethics, 62(1), 87-97.

17. McKinney, J. A., \& Moore, C. W. (2008). International bribery: does a written code of ethics make a difference in perceptions of business professionals. Journal of Business Ethics, 79(1), 103-111.

18. OECD. (2010). Initiative to raise global awareness of foreign bribery: Strategy document. Paris: Organisation for Economic Co-operation and Development Working Group on Bribery in International Business Transactions.

19. PRME. (2012). Anti-corruption guidelines ("Toolkit") for MBA curriculum change. A Project by the Anti-Corruption Working Group of the Principles for Responsible Management Education (PRME) Initiative, United Nations Global Compact.

20. Rabl, T., \& Kühlmann, T. M. (2008). Understanding corruption in organizations - development and empirical assessment of an action model. Journal of Business Ethics, 82(2), 477-495.

21. Rose-Ackerman, S. (2004). Governance and corruption. In B. Lomborg (Ed.), Global, crises, Global solutions (pp. 301-343). Cambridge: Cambridge University Press.

22. SECO. (2008). Korruption vermeiden - Hinweise für im Ausland tätige Schweizer Unternehmen (2nd ed.). Berne: Staatssekretariat für Wirtschaft.

23. Svensson, J. (2003). Who must pay bribes and how much? Evidence from a cross-section of firms. Quarterly Journal of Economics, 118(1), 207-230.

24. Transparency International. (2008). Business principles for countering bribery. Small and Medium Enteprise Edition

25. Tse, A., \& Au, A. (1997). Are New Zealand business students more unethical than non-business students? Journal of Business Ethics, 16(4), 445-450.

26. Vaara, E., \& Faÿ, E. (2012). Reproduction and change on the global scale: a Bourdieusian perspective on management education. Journal of Management Studies, 49(6), 1023-1051.

27. von Alemann, U. (2007). Korruption ist Vertrauenssache. Vortrag vom 6. Dezember 2007 zur Reihe "Universität in der Stadt" im Heinrich-Heine-Institut, Düsseldorf.

28. Wankel, C., \& Stachowitz-Stanusch, A. (2011). Management education for integrity; Transcending amoral business curricula. In C. Wankel \& A. Stachowitz-Stanusch (Eds.), Management education for integrity: Ethically educating tomorrow's business leaders (pp. 3-12). Bingley: Emerald Group.

29. Wankel, C., Stachowitz-Stanusch, A., \& Sekarsari Tamtana, J. (2011). The impact of the national culture dimension and corruption on students' moral competencies - research results. Journal of Intercultural Management, 3(2), 19-45. 